\title{
Max weber e a mística pietista: Uma leitura weberiana sobre a influência pietista no protestantismo histórico brasileiro.
}

Carlos Henrique Souza

\section{Resumo}

Este artigo discute o conceito de mística tendo como referencial teórico Max Weber. A idéia é pensar a mística do protestantismo histórico e sua influência nas missões protestantes do século XIX vindas para o Brasil. A proposta é buscar uma relação entre o movimento pietista surgido na Alemanha e sua influencia na mentalidade do protestantismo missionário, buscando relacionar esta influência com o tipo de protestantismo que se inseriu na sociedade brasileira. Desde já podemos pensar em uma relação entre o movimento pietista e a formação social do protestantismo, em particular, do protestantismo missionário do século XIX, com sua ênfase na experiência mística da conversão pessoal e na formação ascética na mediação pela Bíblia.

Palavras-chave: Max Weber, protestantismo, pietismo, mística, ascese.

\begin{abstract}
This paper discusses the concept of mysticism as a theoretic Max Weber. The idea is to think the mystique of historical Protestantism and its influence on nineteenth-century Protestant missions coming to Brazil. The proposal is to seek a relationship between the Pietist movement emerged in Germany and its influence on the mentality of the Protestant missionary, trying to relate this influence on the type of Protestantism that was introduced into Brazilian society. Since we can think of a relationship between the Pietist movement and the social formation of Protestantism, in particular, the missionary Protestantism of the nineteenth century, with its emphasis on personal conversion experience mystical and ascetic training in mediation in the Bible.
\end{abstract}

Keywords: Max Weber, Protestantism, pietism, mysticism, asceticism.

\section{Introdução}

O objetivo deste trabalho é refletir sobre o conceito de mística em Weber e sua contribuição nos estudos sobre o protestantismo no Brasil. Tomando como análise o movimento pietista e seus reflexos no protestantismo histórico no Brasil, o texto tenta refletir sobre a experiência religiosa protestante e contribuir para as discussões sobre a 
realidade do protestantismo histórico na atualidade e seu crescente processo de carismatização.

Como diria Mendonça (2004: 39) a experiência com o sagrado nunca é totalmente extinta pelas instituições. Sempre ficam alguns rastros presentes nas práticas cotidianas dos fiéis. Sempre há uma sombra. E a essa sombra é o que eu chamo de mística nesta reflexão. Esse espaço é o lugar onde a experiência mística ocorre. É aquilo que não pode ser institucionalizado pelos dogmas e confissões. Esse espaço é o lugar onde a experiência mística ocorre. É aquilo que não pode ser institucionalizado pelos dogmas e confissões.

O que há é um espaço mais ou menos desorganizado, ou às vezes mais ou menos organizado, entre a experiência religiosa, espaço da religião propriamente dita, e a religião instituída, ou igreja. Este espaço pulsa antes da instituição ou no interior dela como um elemento regulador entre sua inércia e dinâmica. (MENDONÇA, 2004: 39).

$\mathrm{O}$ conceito $^{1}$ de mística atualmente tem sido utilizado para se referir aos mais diversos tipos de fenômenos sociais, sejam eles relativos ao universo religioso ou secular ${ }^{2}$. Em primeiro, lugar é preciso deixar claro que não é a pretensão deste trabalho buscar a definição de mística ou sistematizar suas características. O objetivo não é

\footnotetext{
${ }^{1}$ Etimologicamente do grego mystikos, "relativo aos mistérios", e do verbo grego myô, que quer dizer "fechar, calar-se, fechar a boca ou os olhos". Historicamente é uma conexão objetiva com os "cultos mistéricos" onde myéô é o iniciar-se nos mistérios e o termo mystês se refere ao iniciado nos mistérios. Daí surgem usos e atribuições diversas ao conceito que atualmente pode ser usado como necessidade espiritual, busca do sentido da vida (de onde vem e para onde vai o homem). Ela também pode se referir ao fenômeno religioso extraordinário como êxtases, etc. Há também o seu uso como conceito literáriohistórico, quando se fala em épocas místicas da literatura religiosa, quando temos os pontos altos de uma religião (a mística dos padres, a mística alemã, etc.). No sentido da teologia cristã ela teve o seu aparecimento no Ocidente na obra do Pseudo-Dionísio Aeropagita, no livro Teologia Mística, onde ele afirma que na mística "o homem é arrebatado acima de si e percebe que com ele está presente mais que ele próprio", cf. EICHER, P. Dicionário de conceitos fundamentais de teologia, pp. 564 ss. Ver também JAPIASSÚ, Hilton. Dicionário básico de filosofia, em que segundo a definição, mística (lat. nivsticus, do gr. mystikós: relativo aos mistérios), em um sentido genérico, é aquilo que diz respeito ao misticismo, ou que tem um caráter místico. Em um sentido pejorativo, caráter mágico ou misterioso de algo, que exerce fascínio, por ex.: A mística do poder. A mística do artista. A mística de um conjunto de crenças mais ou menos "transcendentes" ao nível da consciência e das práticas, freqüentemente centrado numa representação privilegiada e comandando a ação de um indivíduo ou de um grupo de um modo não racional. Os místicos são pessoas de profunda vivência religiosa, que adotam a mística como modo privilegiado de se relacionarem com o sobrenatural e com Deus.

${ }^{2} \mathrm{O}$ termo é usado indiscriminadamente para se referir a escritores como Paulo Coelho, aos movimentos esotéricos da Nova Era, assim como também aos movimentos sociais, quando se fala da mística do MST ou mística do proletariado (BOFF, 1999: 143). Também há a mística política nas figuras de pessoas como o Luther King e Irmã Doroth, entre tantos outros fenômenos sociais contemporâneos, que por qualquer ponta de mistério e encantamento que tragam a um determinado público são reconhecidos como portadores de uma mística.
} 
compreender a mística por si, mas, fazer uma análise a partir das reflexões de Weber da mística enquanto elemento presente na dinâmica social do fenômeno religioso. Qual a importância da mística para compreender a sua relação com as formas de agência influenciadas pelo espírito do protestantismo no mundo? Como a mística se relaciona com a ética do protestantismo e quais as ligações que podemos estabelecer que nos possibilitem elucidar de que forma o estudo da religião contribui na compreensão dos processos que fundamentam a ação no mundo? Vale lembrar Freund (1970) destacando que o interesse de Weber sobre a religião se justifica pela importância de "estudar o comportamento religioso como uma atividade humana deste mundo (diesseiting), que se orienta significativamente de acordo com fins ordinários” (MENDONÇA, 2004: 134). A partir destas questões iremos refletir sobre mística e suas inter-relações com o protestantismo amplamente discutido no pensamento weberiano.

\section{Mística e Ascetismo como formas de rejeição do mundo.}

$\mathrm{O}$ interesse de Weber em estudar a religião tem como objetivo compreender o processo de racionalização da modernidade. Como ele mesmo se refere a sociologia da religião tem como objetivo contribuir para a "tipologia e sociologia do racionalismo" (WEBER, 1974: 372). Weber estava preocupado em compreender o processo de crise que a racionalidade moderna havia instaurado na sociedade. Ele buscou compreender o processo de racionalização que levava cada vez mais a humanidade para uma vida sem sentido, em um mundo progressivamente desencantado ${ }^{3}$. Neste caso, o estudo do fenômeno religioso tem um objetivo mais complexo do que o de identificar os recursos de opressão ideológica causados pela religião. Em sua análise sobre as religiões no mundo, ele percebe no eixo central do processo de institucionalização religiosa o fenômeno do desenvolvimento da racionalidade moderna. Ao passo que a religiosidade se institucionaliza, ela adensa o processo de racionalização e o conseqüente desencantamento do mundo. Aqui está o epicentro do que levou o autor à análise do fenômeno religioso.

\footnotetext{
${ }^{3}$ Cf. Weber no final da Ética, "Especialistas sem espírito, gozadores sem coração, esse Nada imagina ter chegado a um grau de humanidade nunca antes alcançado”. (WEBER, 2004: 166). O autor mostra no final da obra suas expectativas em relação ao mundo moderno, sentimento que pode ser encontrado nos escritores russos que teve contato, como Tosltói e Dostoiévsky.
} 
Com isso Weber dá uma atenção especial aos meios em que a religiosidade se apresenta nas dinâmicas sociais. A mística aqui representa um estado de manifestação do sagrado que assume um papel importante. A experiência religiosa do místico é aquela que rompe com a instituição.

Porém, Weber estabelece uma relação complexa entre a mística e a ascese, que inicialmente seriam formas de religiosidade contraditórias, mas ambas presentes na ética do protestantismo. Em princípio encontramos uma relação entre a mística e as formas do ascetismo ocidental, pontuando-os como formas de "rejeição religiosa do mundo" ${ }^{4}$. Seu interesse está em definir como as religiões entram em tensão com a ética econômica da sociedade. Neste caso, tanto a mística quanto a ascese são para ele fenômenos que partem da experiência com o sagrado e que podem atuar negando ou aceitando a racionalidade do mundo. E a partir disso se torna possível compreender as relações entre a experiências religiosas e suas influências nas formas de conduta no mundo ${ }^{5}$. Cada um destes dois estados de religiosidade refletem de uma forma na agência. Assim Weber define os conceitos de mística e ascese da seguinte forma:

\begin{abstract}
... o ascetismo ativo é uma ação, desejada por Deus, do devoto que é instrumento de Deus e, por outro lado, a possessão contemplativa do sagrado, como existe no misticismo, que visa a um estado de possessão, não ação, no qual o indivíduo não é um instrumento, mas um recipiente do divino (WEBER, 1974: 374).
\end{abstract}

O ascetismo é o agir de acordo com a vontade de Deus como ocorre na ética protestante e sua valorização do trabalho e na alegria com o mundo. Já o místico é o oposto, pois em um primeiro momento ele é um receptor do sagrado. Sua atitude é contemplativa e irracional, em confronto com o ascetismo que pretende controlar o mundo na ação orientada por Deus e do trabalho enquanto vocação mundana. O asceta contraria o místico em sua fuga contemplativa do mundo. Em outras palavras, o asceta é alguém que age no mundo, que está inserido na sociedade cumprindo sua vocação,

\footnotetext{
${ }^{4}$ Refere-se ao título de um artigo publicado pela primeira vez em novembro de 1915 no Archiv. A versão utilizada, assim como boa parte dos outros textos do autor estão no Ensaios de Sociologia, $3^{\mathrm{a}}$ edição pela Editora Jorge Zahar, de 1974.

5 "Mas assim que, por um lado a reflexão sistemática sobre a prática religiosa e, por outro, a racionalização da vida em geral, com sua crescente especificação dos serviços esperados dos deuses, tenham alcançado certo nível, muito diverso em cada caso concreto, a regra é a formação do panteão, isto é, a especialização e caracterização fixas de determinadas figuras divinas, por um lado, e, por outro, a dotação delas com atributos fixos e alguma delimitação de suas respectivas competências" (WEBER, 2000: 284).
} 
enquanto o místico é aquele que renega o agir em detrimento de uma vida mais contemplativa, rejeitando o mundo.

Contudo tal polaridade é diluída quando Weber analisa os fenômenos voltando-se para a sociedade e seus processos sócio-históricos. Considerando as dinâmicas sociais, tanto o ascetismo quanto o misticismo podem representar a fuga do mundo, uma forma de rejeição da racionalização ocidental, como também fazer o uso de suas ordens. Se o ascetismo se encerra na busca individual presente apenas na própria natureza da pessoa tendo em vista a salvação individual, ele por sua vez se torna um meio de fuga do mundo, mesmo sem a atitude contemplativa do místico. Assim também o místico por sua vez, quando centrado em sua subjetividade, não renuncia ao mundo e fica limitado apenas às formas de ascese, permanecendo nas ordens do mundo em um misticismo "voltado para o mundo" (WEBER, 1974: 374). Neste sentido pode "ocorrer uma certa combinação de ambas as formas de busca da salvação" (Idem), sem desconsiderar a diferenciação que confere ao verdadeiro místico o princípio de não confessar dogmas ou crenças a fim de confirmar sua experiência com o sagrado. Tanto a mística quanto à ascese podem ser formas de rejeição religiosa do mundo, como igualmente elas podem se acomodar na forma de racionalização da experiência religiosa.

No Ocidente, ao contrário, prescindindo-se de representantes isolados de um quietismo específico, que pertencem somente à Idade Moderna, mesmo a religiosidade fortemente mística transforma-se sempre na virtude ativa e então, naturalmente, quase sempre ascética, ou melhor, numa seleção íntima de motivos; são preferidos e postos em práticas aqueles que conduzem preponderantemente a alguma ação ativa, geralmente à ascese (WEBER, 2000: 370-371).

Leonardo Boff na introdução ao O Livro da Divina Consolação de Mestre Eckhart $^{6}$ afirma que o místico não conhece confissões. Partindo deste princípio, o

\footnotetext{
${ }^{6}$ Ver "Eckhart, Johannes, dito Mestre (1260-1327) Teólogo e místico alemão (nascido em Hochheim), mais conhecido como Mestre Eckhart, considerado o criador da linguagem filosófica alemã e o fundador do misticismo ocidental. Depois de algumas viagens a Paris, ensinou cm Estrasburgo e, em seguida, em Colônia. onde respondeu a um processo de heresia que culminou com a condenação de toda a sua obra. Seu pensamento, uma mescla de aristotelismo, agnosticismo, neoplatonismo e de concepções árabes, levava ao panteísmo. Preocupado em esclarecer o que Deus não é, chegou à conclusão de que Deus não existe, porque a existência é uma imperfeição para o Absoluto. Seus Tratados e sermões o situam na origem da mística ocidental. Sua importância filosófica, porém, se deve a seu modo de demonstração. Hegel o considera o precursor de sua dialética. Escreveu ainda: Opus tripartitum e Quaestiones.", Cf. JAPIASSÚ, H. Dicionário básico de filosofia.
} 
místico está em tensão com o mundo de forma externa, ou seja, no que se refere aos meios externos da experiência mística na cultura. As renúncias do mundo começam com a experiência do mistério, presente nas fontes místicas da figura do mágico e do profeta. Eles com seu carisma legitimam a posse do sagrado atraindo seguidores e provocando o movimento de ruptura com a hierarquia das tradições. Assim, passam a conduzir a busca do sagrado revelado a partir da experiência fontal que pode ser a contemplação ou o êxtase religioso. Contudo, este caminho de busca já representa na prática a ascese concomitante à fuga do mundo estreitando a distância entre os dois estados de religiosidade.

\footnotetext{
O contraste diminui, porém, se o ascetismo ativo limitar-se a controlar e superar a malignidade da criatura na própria natureza do agente. Nesse caso, ele fortalecerá a concentração sobre as realizações ativas e redentoras, firmemente estabelecidas e desejadas por Deus, a ponto de evitar qualquer ação nas ordens do mundo (fuga ascética do mundo). Com isso, o ascetismo ativo, em sua aparência externa, se aproxima da fuga contemplativa do mundo (WEBER, 1974: 374).
}

Weber afirma que "para o místico, pelo contrário, o que importa para a sua salvação é apenas a compreensão do significado último e completamente irracional, através da experiência mística" (WEBER, 1974: 375). Vejamos a seguir quais a implicações desta postura do místico em tensão com as dinâmicas sociais do protestantismo na modernidade.

\section{A mística como forma de ruptura com a religião institucionalizada}

Toda a religião surge a partir da necessidade do ser humano de encontrar o sagrado. É o que para Weber constitui a "religião de salvação" (WEBER, 1974: 376). Estas formas de religiosidade por sua vez, já se encontram em um processo de elaboração teológica mais abstrato, racionalizado, com preceitos que devem ser seguidos a fim de assegurar ao que é salvo um estado sagrado, libertando-o do sofrimento de forma radical. Esta experiência ocorre através de cultos orgíacos, êxtase, ascetismo ou contemplação do sagrado.

A partir deste contato com o sagrado, a figura do profeta carismático entra em conflito com os valores do mundo. O encontro com o sagrado pressupõe uma ruptura 
com as estruturas burocráticas do mundo e por sua vez com a religião institucionalizada. Renunciando os elementos racionais da religião, o sagrado e a força irracional da experiência mística traz à tona o princípio protestante da reforma luterana, do temor ao "Deus vivo", ao sentimento de fascinação diante do mysterium tremendum et fascinans - mistério tremendo e fascinante ${ }^{7}$. Em outros termos, é o que Mircea Eliade chama de hierofania, a manifestação do sagrado ou numinoso.

A partir da experiência original - hierofania - as práticas mágicas e proféticas formam o núcleo tanto do ascetismo quanto do misticismo, que logo entram em processo de burocratização da vida religiosa (Id., Ibid.: 375). A mágica desperta o caráter carismático, e de posse do carisma, o mágico passa a uma ação profética no mundo atraindo para si novos adeptos. Tal estrutura tem sua origem na ascese mística presente em todas as religiões de salvação, prometendo aos fiéis a libertação do mal e do sofrimento. Na perspectiva de Weber quanto mais a religião for uma religião de salvação mais ela entrará em confronto com os valores do mundo.

\begin{abstract}
Não obstante, como regra, o profeta ou salvador colocou-se, pessoalmente, em oposição aos poderes hierocráticos tradicionais dos mágicos ou dos sacerdotes. Colocou seu carisma pessoal contra a dignidade deles, consagrada pela tradição a fim de romper seu poder ou coloca-los a seu serviço (Idem, Ibidem: 376).
\end{abstract}

Podemos perceber no texto acima que o místico ao se apresentar como receptáculo do divino, tem a função de espalhar o carisma, tornando-se uma forma de rejeição da racionalização presente das formas institucionalizadas da religião. Assim ocorre o confronto com o clã tradicional que é rejeitado por sua vez, pela força carismática e renovadora da ordem social da experiência mística. O amor caritas (universal) passa a ser mais valorizado que a fraternidade comunitária dos vizinhos (tradição). Deste ponto em diante, Weber diferencia dois princípios fundamentais que se estabelecem nesta experiência do misticismo: O princípio da moral do "nosso grupo" e a do "grupo exterior".

Consecutivamente, quanto mais as religiões criam "imperativos éticos", mais elas se afastam do ideal de fraternidade carismática, diluindo as fronteiras entre o "nosso grupo" e "o grupo exterior”, aproximando-se do amor acósmico que é a base de

\footnotetext{
${ }^{7}$ Cf. Mircea Eliade, é fundamental a obra de Rudolph Otto $O$ Sagrado, onde ele faz uma análise da religião dando primazia à experiência com o sagrado (numinoso) em lugar da metafísica da teologia sobre Deus ou das instituições. ELIADE, M., O Sagrado e o profano: A essência das religiões, p. 23.
} 
toda religião universalista: ajudar ao próximo, à viúva, ao órfão, cuidar dos doentes e dar (WEBER, 1974: 378).

Neste sentido, a religiosidade perde seu poder de crítica aos valores do mundo devido ao processo de racionalização da experiência religiosa. Este processo volta a se repetir sempre quando surge um movimento de renovação religiosa, que parte da experiência mística trazendo novamente a tensão entre a religião e o mundo. Para Weber, estas se resumem à tensões com as comunidades existentes onde a religião de salvação toma quase sempre o aspecto de uma revolução social, já que aspira a uma nova comunidade com base em um princípio ou em uma nova norma - como foi na reforma protestante e no movimento pietista na Igreja Luterana ${ }^{8}$.

O que torna complexa análise weberiana da mística é que ele não se prende ao fenômeno por si. Seu interesse é compreender a experiência do misticismo enquanto forma de rejeição religiosa do mundo. Ele buscou entender como o modo de ação do crente cria e interfere nas formas de sociabilidade, na resistência ao racionalismo ocidental e na ruptura com a institucionalização do sagrado. É neste sentido que a ascese protestante pode ser entendida como um desdobramento do misticismo.

\section{A mística pietista.}

Desde suas origens no século XVI, o protestantismo vivenciou tensões entre o misticismo e a ascese intramundana. Lutero e os reformadores vivenciaram as tensões do início da época moderna, onde a desestruturação dos valores do mundo feudal deu lugar à vida urbana. A Cidade de Deus perdia seu lugar para a Cidade dos Homens. O despertar da consciência e a necessidade de uma salvação pessoal conduziu os espíritos daquele tempo a busca de novos caminhos de salvação, rompendo com burocracia religiosa européia. Lutero viveu essa tensão em sua vida pessoal. Sua preocupação era se aproximar, como diria Weber (1974: 377) das "metas da salvação" o levou através dessa busca pessoal a alimentar a Reforma já em processo na Europa.

\footnotetext{
8 "Movimento de intensificação da fé cristã nascido no seio do luteranismo, na segunda metade do sécuxlo XVII, liderado por Phillip Jacob Spener (1635-1705) e A. H. Francke (1663-1705). O mais conhecido dos escritos de Spener foi o que acabou dando nome ao pietismo, os Pia Desideria (1675). Contra o dogmatismo intelectualista dos teólogos e a ortodoxia doutrinária da Igreja Oficial, o pietismo valorizava uma religiosidade prática de caráter íntimo e fervoroso. Mais que a teologia, importava a piedade cristã: uma conduta de vida centrada na experiência de fé, sentida mais do que pensada, aliada à mais rigorosa conduta moral" (WEBER, 2000: 287).
} 
Contudo, após as disputas religiosas com Roma, o carisma da Reforma luterana se racionaliza, deixando seu caráter místico-profético para assumir uma postura ascética e conciliando o carisma inicial da Reforma com o poder secular do Estado. Se inicialmente a Reforma tivera seu conteúdo místico-carismático ${ }^{9}$ revelando uma rejeição em relação aos valores institucionais, por outro, o processo de definição dogmático e teológico fez recrudescer a força renovadora do misticismo. Mas iremos aqui evitar dualismos. Nem tanto a mística que perdeu seu carisma fontal e tão pouco a ascese "pura" triunfou sobre o êxtase e a emoção. O que ocorreu ao longo dos séculos foi a conjunção de uma mística representada pela ênfase do aspecto emotivo da experiência religiosa somado ao rigor piedoso da vocação protestante destinada à salvação - a ascese. E essa mistura digamos assim, se reverberou ao longo da formação social do movimento protestante.

Foi visto nos desdobramentos históricos do protestantismo nos séculos XVII e XVIII o surgimento do que Weber definiu como moral do "nosso grupo" e do "grupo exterior". Os movimentos reformadores nacionalizados e institucionalizados tornaramse religiões oficiais dos Estados protestantes. A igreja e sua teologia já não significavam nada para a população.

No interior do luteranismo surge então o movimento pietista, liderado por Phillip Jackob Spenner (1635-1705). Uma Alemanha marcada por conflitos políticos com os camponeses, pela crise de produção de alimentos e ondas de desemprego nas cidades, a Reforma apenas representava uma ruptura institucional e política, deixando poucas marcas da influencia de sua espiritualidade na vida cotidiana. A igreja não conseguia responder aos anseios do seu tempo. Em meio a este quadro, as pessoas esperavam uma religiosidade que oferecesse consolo para suas angústias. Neste contexto, surge um movimento social que através da literatura criticava a dureza institucional da igreja em prol de uma religiosidade baseada na emoção e na busca por uma vida mais piedosa. Essa literatura religiosa começou a abrir brechas nas tradicionais barreiras confessionais. Entre as obras fruto deste fenômeno, as mais divulgadas foram a "Imitação de Cristo", do místico alemão do século XIV, Tomás de Kempis que viria se tornar famoso nos círculos protestantes tradicionais no Brasil, com 744 edições em 140

\footnotetext{
${ }^{9}$ Cf. WEBER, M., Economia e sociedade, pp. 325 - 387, o autor faz uma análise do carisma e sua institucionalização nas estruturas de dominação da sociedade. Enquanto a razão revoluciona "de fora para dentro", o carisma tem o poder de a partir de uma metanóia, de manifestar tal revolução de "dentro para fora".
} 
anos; a "Prática da Piedade", do bispo anglicano Lewis Bayly (Oxford, século XVII), com 104 edições; "O Peregrino”, do pregador leigo John Bunyan (Londres, século XVII), também muito lido pelos evangélicos brasileiros, com 61 edições. Na Alemanha "Livros do Cristianismo Verdadeiro", do pastor luterano Johann Arnd, com 123 edições. Jacob Spener foi solicitado para escrever o prefácio deste último, que acabou se tornando um livreto chamado "Pia Desideria" (Desejos piedosos). Além disso, criou os chamados "Colégios de Piedade". Eram grupos pequenos surgidos no século VXII na Inglaterra. Esses grupos se constituíam de leigos reunidos em casas para a leitura devocional da Bíblia (HEITZENHATER, 1996: 20).

O livro de Spenner deu nome ao seu movimento, de forte ímpeto missionário. Enfatizavam a experiência mais que a doutrina, ficando conhecido na Inglaterra como a "teologia do coração". Seu objetivo era reformar a educação teológica, enfatizando o compromisso e a piedade em detrimento do intelectualismo burocrático da instituição ${ }^{10}$.

O movimento pietista se espalha através da literatura e das pregações dos grandes avivamentos do século XVIII e XIX confluindo nas missões protestantes deste período. Os pastores deixam seus templos e partem em direção ao povo, contrariando o clero oficial em nome de sua ética evangélica. Executando estes atos de piedade, acreditavam estar seguindo pessoalmente os passos do próprio Cristo. O carisma perdido na formação da identidade nacional protestante é seguido nos séculos posteriores por uma nova era mística, nascida no seio das igrejas nacionais. Seus reflexos podem ser vistos em figuras como os irmãos Wesley e a tônica das suas prédicas na experiência do coração aquecido ${ }^{11}$. O movimento metodista na Inglaterra foi resultado destas transformações ocorridas no protestantismo.

Esta noite fui com muita má vontade a uma sociedade na rua Aldersgate, onde alguém estava lendo o prefácio de Lutero à Epístola

\footnotetext{
${ }^{10}$ Cf. H.R. Niebuhr, "O presbiterianismo vivia distante da vida religiosa do povo comum com seu intelectualismo e sua ética peculiar. Que tinham a ver a Confissão de Westminster e os discursos eruditos dos teólogos formados na universidade com a piedade dos artesãos e dos pequenos proprietários rurais". (NIEBUHR, 1992: 34)

${ }^{11}$ Cf. MENDONÇA, A., O celeste porvir: a inserção do protestantismo no Brasil, pp. 17-73, sobre a as transformações ocorridas na história da teologia protestante quando o calvinismo tradicional (predestinacionista), influenciado pelos avivamentos na Europa, chega aos EUA e sofre uma mudança no seu dogma principal, onde a predestinação dá lugar à experiência individual e ao esforço ascético na busca pela salvação. Cf. tb. HEITZENRATER, R., Wesley e o povo chamado metodista, pp. 97-134 o capítulo sobre os reavivamentos de 1739 a 1744 na Inglaterra e o surgimento do movimento metodista. O autor faz uma abordagem que contextualiza bem a figura de Wesley no contexto histórico dos movimentos carismáticos no seio do anglicanismo.
} 
aos Romanos. Por volta das oito e quarenta e cinco, enquanto ele estava descrevendo a mudança que Deus opera no coração mediante a fé em Cristo, senti um estranho ardor em meu coração. Senti que confiava em Cristo, somente em Cristo, para a minha salvação; e me foi dada a segurança que ele havia pago os meus pecados e me havia salvo da lei do pecado e da morte (MENDONÇA, 1984:41).

O protestantismo desenvolvido nos séculos posteriores à Reforma experimentou tensões e transformações. A tensão entre a força inovadora do misticismo e os engessamentos posteriores causados pela ascese transformando-o pela a institucionalização do carisma. A mística se perde no processo de institucionalização sofrido pelo protestantismo ao longo da sua história. O misticismo presente no movimento reformador, tendo criado rupturas e um tipo de religiosidade de irmãos de fé, abriu caminho para uma fraternidade movida pelo amor despersonalizado na moral acósmica, distanciando a religiosidade da vida prática. Esta prática pietista e sua ênfase nos valores de uma vida moralmente reta e negadora dos prazeres do mundo é identificada por Weber como o ethos necessário para o surgimento do capitalismo moderno.

\section{A ascese puritana.}

O movimento pietista reanimou elemento místico do protestantismo. Mas como sabemos bem, um outro aspecto forte do ser protestante, desde Calvino, é sua ênfase na racionalidade o no modo de vida ascético. De todas as formas de confronto com o mundo, um dos aspectos mais interessantes é o conflito com o mundo causado pela ascese puritana das seitas protestantes. É notório como a ética do protestantismo nos Estados Unidos é fruto deste processo. Em seu artigo As seitas protestantes e o espírito do capitalismo, escrito a partir de anotações pessoais feitas após uma viagem em solo americano, ele observa um pouco daquilo que ele descreve em suas teorias.

Ao pertencer a uma seita (denominação protestante) o fiel não passa apenas a freqüentar um grupo religioso, mas a ser participante de um "grupo interior", onde tal pertencimento se torna a credencial para todos os tipos de relacionamentos comerciais na sociedade. Weber observou o evento de um amigo dentista ao relatar que um dos pacientes, ao entrar em seu consultório e sentar-se na cadeira, logo se apressou em dizer que pertencia a uma determinada seita (WEBER, 1974: 349). Fazer parte de uma seita era sinônimo de que o sujeito era portador de qualidades morais que o tornava um bom 
cliente. Não é sem motivo que Benjamim Franklin, em um trecho da Ética protestante diz: "Um bom pagador é senhor da bolsa alheia" (WEBER, 2004: 43).

É possível neste ponto determinar a tensão entre a "religião fraternal" e o mundo, em que o misticismo dá lugar a uma ascese intramundana deixando seu caráter comunitarista e abraçando a fraternidade do "grupo interno" racionalizada pela ascese. Para entrar nas seitas protestantes os fiéis faziam verdadeiros sacrifícios. Como por exemplo, a cerimônia do batismo nas águas frias do norte da América, onde os crentes ignoravam o frio e o risco de adoecimento por medo do inferno e na esperança de obter crédito financeiro (WEBER, 1974: 350). Mas ainda sim, esta ascese do puritanismo calvinista não significa total ausência de uma mística.

\title{
5. A mística ascética do protestantismo missionário do século XIX.
}

Se considerarmos o misticismo tradicional, contemplativo, como o de São João da Cruz, Santa Teresa, Mestre Eckart, podemos dizer que o protestantismo se tornou puramente ascético. Contudo, ao olhar para o protestantismo do século XVIII até fins do século XIX, podemos pensar em uma mística ascética protestante presente nos movimentos espirituais de renovação (Revivals) que representaram uma junção entre o misticismo e ascese intramundana. Estes movimentos avivalistas se fizeram presentes na tradição protestante das missões no século XIX, causando repercussão no protestantismo histórico no Brasil. Falamos de um protestantismo influenciado pela mística pietista através de uma religiosidade que se expressa através do individualismo, da subjetividade, da observância moral de valores do mundo liberal burguês.

\begin{abstract}
Durante todo o século XIX, imperava a idéia de que a religião e civilização estavam unidas na visão da América cristã e que Deus tem sempre agido através dos povos escolhidos, os de língua inglesa, escolhidos mais do que quaisquer outros, são obrigados a propagar as idéias cristãs e a civilização cristã. Alguns autores escreveram que a mais alta expressão da civilização anglo-saxônica eram os Estados Unidos. Um ministro metodista disse: Deus está usando os anglo-saxões para conquistar o mundo para Cristo a fim de despojar as raças fracas e assimilar e moldar outras. $\mathrm{O}$ destino religioso do mundo está nas mãos dos povos de fala inglesa. À raça anglo-saxã, Deus parece ter entregue a empresa de salvação do mundo. (MENDONÇA, 1984:61)
\end{abstract}

A figura do burguês liberal, com sua ética puritana voltada para o mundo, guardando porém uma conduta piedosa no seguimento fiel dos Evangelhos, acreditando que em seu esforço missionário está seguindo os passos de Cristo. Tal experiência pode 
ser encontrada espírito deste protestantismo marcadamente místico e ascético. A exemplo podemos citar a experiência religiosa dos missionários protestantes, como William Carey (1761-1834), pioneiro das missões, David Livingstone (1813-1873), missionário na África e Albert Schweitzer (1874-1965), igualmente missionário na África. A atuação missionária destes personagens nos remetem a um protestantismo permeado pelo pietismo alemão, que passaram por uma experiência místico-ascética da conversão pessoal. Para Mendonça (1998), estes e outros são produtos de um tipo de protestantismo que rompeu com o protestantismo nacionalista pós-Reforma (os avivamentos nos EUA e na Europa).

O exemplo dos primeiros missionários metodistas expressa bem tal mentalidade. Em geral os missionários tinham uma preocupação comum com dois fatores: A experiência de conversão e a leitura devocional da Bíblia. Era preciso passar pela experiência do coração aquecido como marca da conversão. Conseqüentemente a conversão levaria o fiel a uma vida piedosa que seria sustentada pela pelo aprendizado obtido com a leitura da Bíblia. Estes dois elementos, experiência conversão e leitura da Bíblia representam estes dois elementos do lado tanto místico quanto ascético do protestantismo histórico no Brasil. E tudo isso ainda estava relacionado ao projeto civilizatório que estava incutido nestas missões. É preciso destacar que a moralidade observada pelo pietismo protestante é uma moral pautada nos valores da civilização norte-americana do destino manifesto. Como destaca um missionário metodista ao falar sobre a importância e a relação entre a evangelização protestante como forma de trazer os valores da modernidade para o Brasil.

\begin{abstract}
Imediatamente após a minha chegada, iniciei cultos públicos na minha residência. A assistência logo aumentou de trinta para quarenta, e assim fomos obrigados a procurar um lugar maior e mais conveniente (...). Conseguimos organizar uma escola dominical, denominada Escola Dominical Missionária Sul-Americana, auxiliar das Escolas Dominicais da Igreja Metodista Episcopal (REILY, 2003: 102).
\end{abstract}

Veja a ênfase dada à conversão mediada pela leitura da Bíblia ${ }^{12}$. Em outro trecho o missionário destaca o avanço das escolas metodistas no Brasil.

\footnotetext{
12 Cf. LEONEL, J., História da Leitura e Protestantismo Brasileiro. Trabalho interessante, faz uma análise sobre a literatura do protestantismo brasileiro considerando a influência do movimento pietista. $\mathrm{O}$ autor analisou diários dos primeiros missionários presbiterianos e a tradição da leitura bíblica.
} 
Sob recomendação e pedido de alguns dos meus amigos aqui, abri uma escola diária ... Geralmente, crê-se que o estabelecimento de escolas de aprendizagem sobre princípios largos e liberais será um dos meios mais diretos de acesso ao povo deste país. (...) Porque não se cultivam aqui as artes e ciências como na Inglaterra e na América do Norte? O opróbrio cai principalmente sobre eles [o clero romano].. (Id., Ibid.: 103)।

Por um lado ele trouxe a mística pietista através dos valores da modernidade. Esse misticismo protestante mesclou a experiência religiosa centrada na emoção, na subjetividade que é um valor da modernidade. Por outro lado, esse fenômeno estava ancorar nos valores da civilização moderna, ou seja, a observância moral era pautada no estilo de vida do liberalismo.

\begin{abstract}
O misticismo protestante que neste trabalho assume as feições do que chamamos pietismo romântico, pois tem as seguintes características: é um movimento, ou presença, no interior das igrejas mas que corre à margem dos seus sistemas de poder, isto é, dogmas e confissões, e que cultiva romanticamente a convicção no auto-aperfeiçoamento humano por intermédio da devoção disciplinada da leitura da Bíblia e meditação nela. O componente central do misticismo protestante é a liberdade do cristão - livre exame e busca pessoal de Deus em Jesus Cristo - e tem como consequiência a criação e manutenção de uma ética pessoal e social (MENDONÇA, 1998: 5).
\end{abstract}

Segundo Hérvier-Lérger (2008: 168), o místico é um terceiro tipo de agrupamento não tão claro dentro das formas religiosas, que não está preocupado em seguir uma justificação dogmática a respeito da religião. A exemplo do cristianismo, Jesus reuniu indivíduos que decidiram pessoalmente segui-lo. A Reforma então foi quem disseminou essa característica onde o Reino passou a ser compreendido como algo que está dentro de cada pessoa. A despeito da pluralidade de experiências presentes nos avivamentos ocorridos durante dois séculos, a teologia desses movimentos pode ser definida nos moldes de um calvinismo modificado contendo uma concepção mais ética de Deus, ênfase na liberdade e responsabilidade humanas e nas virtudes do amor (MENDONÇA, VELASQUEZ, 2002: 88). Observemos que este último elemento foi a temática predominante na vida e obra dos missionários que se desprendiam em prol de um ideal romântico de ir em direção ao mundo, mas ao mesmo tempo resistindo a ética do mesmo através de uma vida pautada na piedade. Trata-se de uma experiência mística ascética por ser simultaneamente uma forma de fuga do mundo, que acontece no interior das igrejas mas independente das mesmas, buscando uma nova ética de vida no mundo, sendo avesso aos dogmas e instituições. 
Não se quer aqui igualar a mística deste protestantismo com os místicos clássicos como São João da Cruz e outros. Até porque, como já vimos, o monge que se reclusa ao faze-lo já está inserido em uma forma de ascese, atraindo seguidores em torno de seu carisma. A questão é compreender a mística presente neste protestantismo que possui uma racionalidade mediada pela leitura da Bíblia e cheia de um fascínio pela personalidade de Jesus que leva as pessoas ao desejo de vê-lo como foi visto em seu tempo (MENDONÇA, 1998: 8). Este é um aspecto importante para compreender o protestantismo, pois, "se falamos em ética protestante, falamos em ética ascética mundana, o que quer dizer um misticismo acompanhado de sua correspondente racionalidade" (MENDONÇA, 1998: 13). Ou seja, o protestantismo místico ascético norte-americano, de onde saíram as correntes vindas para o Brasil, foi capaz de conjugar o caráter místico - em se tratando da experiência do coração aquecido e a conversão por meio de uma revelação pessoal característicos dos Revivals - e o discurso ascético intermediado pela leitura devotada das Escrituras. Da mesma forma como podemos perceber uma forma de ascese, também é possível ler o fenômeno do protestantismo pietista a partir de uma experiência não racional, pois nele não há uma busca de razão para a fé e sim uma aproximação pessoal com o Jesus de Nazaré.

\begin{abstract}
Como dizem eles mesmos: é necessário, de vez em quando, realimentar o espírito. Este misticismo é tipicamente protestante. Ele guarda traços do monasticismo por ser individual ou de pequenos grupos e exercitando a parte do mundo e em tempo separado. Espaço e tempo separados (a solidão do quarto ou o lugar de retiro) a fim de compensar a racionalidade do estar no mundo com sua ética ascética (Id., Ibid.: 5) .
\end{abstract}

\title{
Considerações finais
}

Se por um lado vimos que misticismo e ascetismo possuem uma relação um tanto quanto complexa, algumas considerações finais podem ser feitas, mesmo reconhecendo as limitações deste trabalho. A ascese originada no devir místico mantém em alguns casos elementos da mística, como a busca pela salvação e aproximação com o sagrado por meio de uma vocação ou esforço. Mas o que diferencia, segundo Weber, os dois estados de rejeição religiosa do mundo é o aspecto irracional e hostil da experiência mística a qualquer forma de racionalização. Enquanto no ascetismo do 
mundo ocorre a apropriação de uma ética intramundana que acomoda a prática religiosa com os valores do mundo, na mística ocorre a rejeição de toda a racionalidade.

O místico em sua prática religiosa, ainda que inserido no mundo, é levado a agir negando seus valores. Ele ama, não pelo objetivo que há no amor mas pelo amor por si. Ele "doa sua camisa simplesmente para a pessoa que cruza seu caminho acidentalmente e lhe pede o paletó" (WEBER, 1974: 382). Seu amor é desobjetivado, não faz parte de uma ascese que deseja ser aceita em um grupo moralmente definido. Seu interesse é a doação descompromissada. Mas este comportamento leva a um outro processo.

Ao romper com a ética econômica, o amor benevolente do misticismo acaba por participar da lógica intramundana. $\mathrm{O}$ monge recluso no mosteiro participa indiretamente dela, onde para Weber "até mesmo a reclusão contemplativa fez suas concessões" (WEBER, 1974: 341).

Sendo assim, reduzir um tema tão complexo a dualidade entre mística e ascetismo é limitar as possibilidades de leitura que podem enriquecer o estudo do fenômeno religioso pelas Ciências Sociais. Além do mais, Weber não tem como seu objetivo estudar a mística ou a ascese em si, e sim como estas duas formas de experiência religiosa se dão historicamente através da ação no mundo. No entanto alguns aspectos são bem claros para ele: Enquanto o asceta procura a vocação divina do seu agir no mundo, o místico vive em tensão com o mundo onde "a criatura deve se calar para que Deus possa falar" (WEBER, 1974).

A experiência mística segundo ele é o instante de ruptura com a hierarquia e a tradição, pois a mística por ser irracional torna a ação do indivíduo uma ameaça à ética do mundo dirigido racionalmente. O místico é uma ameaça por que este está possuído pelo sagrado que é irracional. Mas o místico, a partir da experiência mágica, gera o carisma que em suas formas históricas acabam atraindo para si seguidores, promovendo as transformações sociais na história. Transformações que são geradas por um carisma de origem magia que logo chegará por meio da ascese intramundana, a novos dogmas de um grupo que se fecha em valores internos contrários aos do mundo. É o que ele denomina como rejeição religiosa da ética econômica.

A mística-ascética do protestantismo pietista é uma forma de alinhar os processos históricos que envolveram ao longo dos séculos a experiência fundadora da Reforma - como a mística de Lutero - e ao mesmo tempo, esta mesma experiência que foi geradora de formas de ascese que permitem aos seguidores participar de um certo 
carisma. É no chão da existência que a experiência assume seu papel norteador da vida e das dinâmicas sociais. No emocionalismo das classes populares, na sua forma mais rudimentar de vivência religiosa, eles nos revelam a centralidade do papel da subjetividade no fenômeno religioso. Existe um elemento interessante na experiência protestante atual na sociedade brasileira. A Reforma do século XVI representou até certo ponto, o fim da predominância da sociedade feudal estamental e o surgimento do individuo moderno com sua religiosidade voltada para a subjetividade, ancorada na experiência pessoal da fé. Ao romper com a tradição católica medieval, o protestantismo trouxe para o mundo uma religiosidade pautada na experiência do sujeito, na crença individual e na fé mediada pelas escrituras.

\begin{abstract}
A religião das classes incultas e economicamente expropriadas, que correspondem às necessidades desses grupos. Um dos traços comuns é o fervor emocional, onde o poder do pensamento abstrato não chegou a se desenvolver plenamente e não se inibiu a expressão emocional por meio de convencionalismos bem educados, a religião se expressa e se expressará em termos emocionais. Nestas circunstâncias a espontaneidade e o vigor dos sentimentos religiosos, mais do que a conformidade a credos abstratos, são vistos como provas da genuína religiosidade. (NIEBUHR, 1992: 27)
\end{abstract}

A experiência religiosa do protestantismo pietista dos séculos XVIII e XIX (que mais tarde foi base do protestantismo que veio para o Brasil) é o exemplo de uma mística que ao simultaneamente se constituiu ascética em toda a sua ética puritana (a liberdade individual, o poder da decisão pessoal por Cristo, os valores como não beber, não fumar, etc.) que são necessários para estar em contato com o sagrado. Não estamos nos referindo a uma religiosidade puramente racional mas também não se trata de uma religiosidade onde só há e êxtase, sem nenhuma sistematização teológico-doutrinária. Se trata de compreender um fenômeno que transcende aos conceitos mas que é um desafio diante da velocidade das transformações ocorridas no campo religioso brasileiro.

\title{
Referências Bibliográficas:
}

EICHER, P. Dicionário de conceitos fundamentais de teologia, São Paulo: Paulus, 1993.

ELIADE, M. O Sagrado e o profano: A essência das religiões, Edições Lisboa, 1983. 
FITZER, Gottfried. O que Lutero realmente disse, Rio de Janeiro: Editora Civilização Brasileira, 1971.

FREUND, Julien. Sociologia de Max Weber, Rio de Janeiro: Editora Forense, 1970.

HEITZENRATER, Richard, Wesley e o povo chamado metodista, Rio de Janeiro: Editeo, 1996.

HERVIEUR-LÉRGER, Danièle. O peregrino e o convertido: a religião em movimento. Petrópolis, RJ: Vozes, 2008.

LEONEL, João, História da Leitura e Protestantismo Brasileiro. São Paulo:

Universidade Presbiteriana Mackenzie e Paulinas Editoras, 2010.

LINDBERG, Carter, As reformas na Europa, São Leopoldo: Sinodal, 2001.

LUTERO, M. Sobre a Autoridade Secular. 1ªed. São Paulo: Martins Fontes, 1995.

MENDONÇA, Antonio Gouvêa. O protestantismo latino-americano entre a racionalidade e o misticismo, In: VIII JORNADAS SOBRE ALTERNATIVAS RELIGIOSAS NA AMÉRICA LATINA. Versão on-line disponível em http://www.centroestudosanglicanos.com.br/bancodetextos/ecumenismo/o_protestantismo_latino america no.pdf [acessado em 03/08/2010].

Paulo: Ed. Loyola, 2002.

VELASQUES FILHO, Introdução ao protestantismo no Brasil, São O celeste porvir: a inserção do protestantismo no Brasil, São Paulo: Paulinas, 1984.

NIEBUHR, H. Richard, As origens sociais das denominações cristãs. São Paulo: IEPG-ASTE, 1992.

REILY, Duncan Alexander. História Documental do Protestantismo no Brasil. $3^{\mathrm{a}}$. Edição, São Paulo: ASTE, 2003

WEBER, M., A ética protestante e o "espírito" do capitalismo, São Paulo: Cia. Das Letras, 2004.

, Ensaios de Sociologia, Rio de Janeiro: Jorge Zahar Editores, 1974.

Economia e Sociedade: fundamentos da sociologia compreensiva. Brasília: Editora UNB, 2000, 2009 (reimpressão). 